\title{
An interactional expertise-based approach to specialized inverse translation
}

Igor Antônio Lourenço da Silva*

\section{Background}

Inverse translation, i.e., from the translators' or the very field specialists' L1 to their L2 (LORENZO 1999), has been widely undervalued or condemned in several markets, including in Brazil (e.g., BOTTMAN 20181), and in the very Translation Studies (e.g., NEWMARK 1981; KELLY et al. 2003). Nonetheless, translation of specialized, usually scientific, texts from Portuguese into English is a common practice in Brazil (cf. VASCONCELOS; SORENSON; LETA 2007; PAGANO; DA SILVA 2008), typically as a practice of inverse specialized translation.

Few studies have approached inverse translation (e.g., BEEBYLONSDALE 1996; CAMPBELL 1998; BUCHWEITZ; ALVES 2006; PAVLOVIĆ 2007; FERREIRA et al. 2016), let alone specialized inverse translation (e.g., BRAGA 2012; DA SILVA 2015; DA SILVA; SILVEIRA 2017). On top of that, research into specialized translation in general has been mostly limited to terminological issues (e.g., AUBERT 2001; KRIGER 2006; PAIVA; CAMARGO; XATARA 2008; FROMM 2018) or technical issues, including the use of translation memories, corpora, or machine translation (e.g., FRÉROT 2016), a pattern which Byrne (2006) observed over one decade ago.

\footnotetext{
* Universidade Federal de Uberlândia (UFU)

${ }^{1}$ In a post on Facebook published on November 14th, Denise Bottman, a professional Brazilian translator, says: "sempre me espanto um pouco quando procuram brasileiros para fazer versões do português para o inglês (...). acho muito, muito difícil, para não dizer altamente improvável, que um tradutor não nativo disponha do amplo e variado instrumental linguístico, às vezes até intuitivo e inconsciente, para fazer uma boa versão." In English: "I'm always a little shocked when someone looks for Brazilians to translate from Portuguese into English (...). I think it's very, very hard, not to mention highly unlikely, that a nonnative translator has the wide and varied linguistic material, at times an even intuitive and unconscious device, to produce a good L1-L2 translation."
} 
In this author's past experience working with field specialists in a world-leading research center devoted to diagnosis of genetic disorders and newborn screening in Brazil, researchers face difficulties in finding qualified translators, as most professionals usually lack both command of the scientific genre and command of the content provided in the original texts. Their translations usually fail despite the several glossaries available in the field. As a result, most researchers in that center prefer translating or producing their own texts after frustrated experiences with translators (see PAGANO; DA SILVA 2008). A significant part of them is even able to deliver more adequate translations than the translators themselves (see BRAGA 2012).

Based on Collins \& Evans's (2007) sociological concepts of contributory expertise and interactional expertise, two types of specialized tacit knowledge, it comes with no surprise that some Brazilian researchers excel at translation tasks. Contributory expertise is the highest level of specialized expertise and is found amongst those individuals who effectively produce or work within a given domain. In general terms, contributory expertise is the kind of tacit knowledge that enables an individual to perform within a domain (e.g., surgeons who operate a patient, civil engineers who project buildings), which also includes writing in most domains, including research (KELLOG 2006). Meanwhile, interactional expertise, which is located right below contributory expertise, implies encyclopedic knowledge and language fluency in a given domain without the practice counterpart. This is the kind of knowledge used by reviewers, sociologists and translators to perform most of their tasks after conversations and interactions with those with contributory expertise.

As contributory experts, Brazilian researchers have mastery of both subject matter and language not only in Portuguese but also in English, since writing in or translating into English has become a paramount condition to their academic recognition worldwide (KELLOG 2006; VASCONCELOS; SONRENSON; LETA 2007). As such endeavors take a substantial amount of their time that could be devoted to research, specialized inverse translation is still an important niche for qualified translators in Brazil, who should - as contended below-rely not only on terminological aids, but most importantly on developing interactional expertise. Following Collins \& Evans 
(2007), interaction with field specialists is a crucial condition for a translator to develop the language needed to produce a text that passes as an output by a member of the target discursive community.

Interactional expertise may even be of paramount importance in social interactions, as shown by Ribeiro (2007). The author interviewed four Japanese-Portuguese interpreters from an iron and steel company in the State of Minas Gerais, Brazil. He observed that these interpreters' interactional expertise enabled them to detect content and language problems in the interactions between Japanese and Brazilians. In their interpreting, they managed to mitigate the impact of such problems, which successfully provided the conditions for the technology transfer desired by the company managers.

Even though terminology is important in any domain (e.g., PAIVA; CAMARGO; XATARA 2008; ISQUERDO; FINATTO 2010; FINATTO 2018), terminological (declarative) knowledge is only a part of expertise, which is mostly based on tacit knowledge. A specialized translator needs specialized tacit knowledge to understand a specialized source text and work on both content and discourse levels in his/her writing of the target text. In Scardamalia \& Bereiter's (1991) words, this is writing though a knowledge transformation process, rather than through a knowledge transference process, i.e., simply transferring the textual material from one language to the other. In the knowledge transformation process, an individual engages in extensive planning for problem solving in two interconnected spaces: 1) the content space, with problems pertaining to understanding the field (domain knowledge), and 2) the rhetorical space, with problems pertaining to text writing (discourse knowledge).

As language is socially construed (see HALLIDAY 1977), it follows that translation, writing and reading, amongst several other language practices, require interactions in a social context. In fact, socialization in practices of a group are of essence for any expert, whether a contributory or an interactional expert. It requires time and effort to lead to specialized tacit knowledge, i.e., deep understanding of "rules" that cannot be expressed, as they are only acquired by an individual in his/her practices with the social group. 
Based on Collins \& Evans's (2007) expertise model, this article contends that interactions between translators and field specialists are of essence to the production of target texts that meet the expectations of the target discursive communities. As such, developing interactional expertise is a promising premise in the translator's (continued) training and is fundamental to globally disseminating the knowledge produced in the Brazilian territory. The understanding of how such expertise can be acquired and how it impacts on the translator's performance and translation product may eventually help translator trainers design courses that are based not only on terminological and technical aids, but most importantly on real-life interactions with field specialists.

In the following sections, a personal sample and a sample from a study with four female translators are provided to show how relevant interactional expertise is for specialized translation. ${ }^{2}$ The samples evince that terminology itself is not the core translation problem, as terminological equivalents can be relatively easily found in dictionaries, glossaries, corpora, and at times in machine translation engines. The core translation problem is related to both understanding the source text and producing an adequate target text, which requires specialized tacit knowledge.

\title{
Discussing two samples
}

Let us start with sample A, obtained through the author's personal experience. A1 is the source text, followed by its gloss A1.1.

\begin{abstract}
A1) A Doença Falciforme (DF) é hemoglobinopatia autossômica recessiva causada por alteração na estrutura da hemoglobina $(\mathrm{Hb})$. Caracteriza-se pela ocorrência de falcização das hemácias e hemólise, levando à diminuição da quantidade de oxigênio que chega aos tecidos, resultando em lesão tecidual aguda e crônica, o que determina elevada taxa de mortalidade precoce. O diagnóstico é, geralmente, realizado no rastreamento neonatal ou na infância.
\end{abstract}

\footnotetext{
2 The study was approved by the university's ethics committee (Approval No. 989152, as of 13 March 2015).
} 


\begin{abstract}
A1.1) Falciform disease (DF) is autosomal recessive hemoglobinopathy caused by alteration in the structure of the hemoglobin $(\mathrm{Hb})$. [It] is characterized by the occurrence of sickling of the red blood cells and hemolysis, leading to a decrease in the amount of oxygen that reaches the tissues, resulting in acute and chronic tissue damage, which determines an increased rate of early mortality. Diagnosis is usually made in newborn screening or in childhood.
\end{abstract}

The repetitive use of both nominalizations ("alteração" / "alteration," "falcização" / "sickling," and "diminuição" / "decrease") and reduced hypotactic clauses that are introduced by a gerund verb ("levando" / "leading," and "resultando" / "resulting") or by a wh- element (in "o que determina" / "which determines") clouds the understanding of the relationships between the participants in the clauses, as well as of time sequence and/or cause-effect relationships. A lay translator may figure out that the writing is poor in Portuguese, yet $\mathrm{s} /$ he will not manage to improve the writing in the target text, since any change to implicit meanings may spell out relationships that are false in the real life. For instance, a layperson cannot tell whether hemolysis alone leads to reduced amounts of oxygen or both sickling and hemolysis are responsible for that. Also, such a person cannot tell the origin or outcome of the sickling: Do the red blood cells lead to the sickling of something or are they themselves turned into sickle-shaping cells? As a result, the target text may probably be a text that resembles a machine-translated output as the one in A1.1.

Nonetheless, interaction between translator and field specialists may lead to the writing of a target text that is more readable than the very source text, as in A1.2.

\footnotetext{
A1.2) Sickle cell disease (SCD) is an inherited disease in which the predominant presence of sickle hemoglobin $(\mathrm{Hb} \mathrm{S})$ in red blood cells leads to sickling, vasoocclusion, and chronic hemolytic anemia. This results in decreased delivery of oxygen to tissues and causes acute and chronic tissue and organ injury. SCD is associated with high mortality rates, especially in young children. It is usually diagnosed in childhood, ideally through newborn screening. Affected infants typically become symptomatic after four months of life.
} 
The writing in A1.2 was obtained after a first draft translation produced by the author of this article and revisions provided by the field specialists and the translator himself. It provides the origin of the sickling process and spells out that the tissue and organ injuries are the result of all previously mentioned variables, namely: sickling, vasoocclusion, and chronic hemolytic anemia. As contended in the previous section, the core problem is not terminological. Even a free machine translation engine could provide adequate terminological solutions, as in A1.3:

A1.3) Sickle cell disease (DF) is autosomal recessive hemoglobinopathy caused by a change in hemoglobin $(\mathrm{Hb})$ structure. It is characterized by the occurrence of red blood cells and hemolysis, leading to a decrease in the amount of oxygen that reaches the tissues, resulting in acute and chronic tissue damage, which determines a high rate of early mortality. Diagnosis is usually made in neonatal or childhood screening. (Google Translate, 17 March 2019)

Let us see a second sample, B, obtained in a study with four professional translators who declared they had had some experience in translating medical texts, but no interactional expertise in the medical domain.

B1 is the source text, followed by its gloss B1.1.

B1) Utilizou-se a tonometria de aplanação, em que os pesquisadores pressionaram suavemente a artéria carótida e verificaram a onda de pulso gerada. A onda de pulso é derivada na aorta ascendente, produzindo uma quantidade importante de dados cardiovasculares.

B1.1) Applanation tonometry was used, in which the researchers gently pressed the carotid artery and verified the generated pulse wave. The pulse wave is derived in the ascending aorta, producing a significant amount of cardiovascular data.

All four translators (S1, S2, S3, and S4) mentioned they were at odds to understand the source text and translate the terms in B1. In their opinion, the terms in the text were: "tonometria de aplanação" / "applanation tonometry," "artéria carótida," / "carotid artery," “onda de pulso" / "pulse wave", 
"aorta ascendente" / "ascending aorta," and "cardiovascular," / "cardiovascular." They used Google Scholar to identify the terminological equivalents. Their outputs were as follows:

B1.S1) Applanation tonometry method, by which researchers gently press the patient's carotid artery, was used to measure pulse wave, which stems from ascending aorta, producing important cardiovascular data.

B1.S2) Applanation tonometry was used and through that researchers lightly pressed the carotid artery to gauge the pulse wave produced. The pulse wave is branched in the ascending aorta, and it produces a number of important cardiovascular data.

B1.S3) The researchers used applanation tonometry, as they gently pressed the carotid artery and verified the created pulse wave. The pulse wave was felt in the ascending aorta, producing an important amont of cardiovascular data ${ }^{3}$

B1.S4) Researchers used the applanation tonometry to verify the pulse wave velocity generated there by slightly pressing the carotid artery. The pulse wave derives from the ascending aorta and produces a significant quantity of cardiovascular data.

As shown in the examples above, all translators translated the five potential terms equally. However, they failed to identify a sixth term - "é derivada" / "is derived" - which led to four different translations. In fact, the gauging or measuring of pulse wave is derivative, i.e., based on a mathematical function. The problem was that the term was not typical of Medicine, but rather of Mathematics. Most probably, only someone familiar with Mathematics or with the pulse wave method would be able to spot the term as such.

As a result, S1, S2, S3 and S4 translated "é derivada na" / "is derived in the" as "stems from," "is branched in the," "was felt in the," and "derives from the," respectively. None of such renderings are terminologically correct

\footnotetext{
${ }^{3}$ Typo and lack of punctuation as in the output provided by the translator.
} 
or adequate, including "derives from," as it does not refer to a derivative obtained in the ascending aorta.

Such translation problem may be terminological in part, but once again it depends on the understanding of the domain. Had it been terminological only, all translators would have spotted the verb "derive" as the most likely candidate for a formal correspondent, as it is similar to "derivar" in Portuguese.

In other words, the translator is supposed to have a deeper understanding of the domain in which or for which s/he is translating. Terminology is helpful if a translator really knows a term and understands its semantic traits and its relationships with other terms in the domain. However, assuming that limited knowledge of a list of terms (signifier in Portuguese $=$ signifier in English) will solve a translation problem is a prerogative that is doomed to failure.

As sample B seems to show, even a fruitful use of terminology depends on previous knowledge, usually gained through interactions with specialists, so that the translators can understand the source text, pinpoint all potential terms, and produce suitable target texts. This is highly specialized tacit knowledge, which is not explicitly expressed in rules, but rather learnt socially through practice and interaction with the discourse members.

Both samples A and B provide pieces of evidence for an approach to specialized translation through interactional expertise. In sample $A$, the translation problem was solved by having both translator and field specialists working together, which is very rare in the profession and also dependent on the field specialists' good command of the English language. In sample $B$, the translation problem was not spotted by the translators probably because they lacked interactional expertise, even though they had had some experience in the domain. This seems to show that acquiring interactional expertise takes time and effort, thereby entailing a shift in paradigm: from one with the translator capable of translating anything provided it has some resources including terminological aids, to one with the translator dependent on a kind of membership to a discourse community. 


\section{Final remarks}

It goes without saying that professional translators do not have contributory expertise in the medical domain. However, they can develop the necessary language to walk smoothly amongst the members of the medical domain when it comes to written text production. This involves not only declarative knowledge of terms and jargons, but most importantly specialized tacit knowledge.

Interactional expertise seems to be a potential avenue in the (continued) training of specialized translators, but it requires long socialization and cooperation between field specialists and translators. Further studies should approach how to maximize the interactions so that the translator does have several resources at hand, including enough tacit knowledge to make the best use of a terminological database.

All in all, Translation Studies should recognize specialized inverse translation as a legitimate practice, especially in milieus where this practice proves to be highly necessary. The samples herein discussed seem to show that, at least for specialized inverse translation, the problem is not actually how "wide and varied" the translator's "linguistic material" is in the L2, but rather how deep his/her understanding of a domain is in both L1 and L2.

\section{Acknowledgement}

Part of this study was developed with a grant provided by the National Council for Scientific and Technological Development (CNPq grant no. 461054/2014-0) and with the support of field specialists from the School of Medicine, Universidade Federal de Uberlândia. The author is also thankful to Nilfan Fernandes da Silva Júnior and Shanti de Nogueira França, who translated an early draft from this article in an undergraduate course on inverse translation.

\section{References}

AUBERT, Francis H. Tradução técnico-científica e terminologia: um ensaio exploratório de uma via de mão dupla. Tradterm, São Paulo, v. 7, p. 41-52, 2001. https://doi.org/10.11606/issn.2317-9511.tradterm.2001.49141. 
BEEBY-LONSDALE, Alisson. Teaching Translation from Spanish to English. Ottawa: University of Ottawa Press, 1996.

BUCHWEITZ, Augusto; ALVES, Fabio. Cognitive Adaptation in Translation: An Interface Between Language Direction, Time, and Recursiveness in Target Text Production. Letras de Hoje, v. 41, n. 2, p. 241-272, 2006.

BRAGA, Camila Nathália de Oliveira. O texto traduzido sob a perspectiva do avaliador: um estudo exploratório. 2012. 150 f. Programa de Pós-Graduação em Estudos Linguísticos, Faculdade de Letras, Universidade Federal de Minas Gerais, 2012.

BYRNE, Jody. Technical Translation: Usability Strategies for Translating Technical Documentation. Dordrecht: Springer, 2006. https://doi.org/10.1007/1-4020-4653-7.

COLLINS, Harry; EVANS, Robert. Rethinking expertise. Chicago and London: University of Chicago Press, 2007. https://doi.org/10.7208/chicago/9780226113623.001.0001.

FERREIRA, Aline; SCHWIETER, John Wayne; GOTTARDO, Alexandra; JONES, Jeffery. Cognitive Effort in Direct and Inverse Translation Performance: Insight from Eye-Tracking Technology. Cadernos de Tradução, Florianópolis, v. 36, n. 3, p. 60-80, 2016. https://doi.org/10.5007/21757968.2016v36n3p60.

FRÉROT, Cécile. Corpora and Corpus Technology for Translation Purposes in Professional and Academic Environments: Major Achievements and New Perspectives. Cadernos de Tradução, Florianópolis, v. 36, n. 1, p. 36-61, 2016. FINATTO, Maria Jose B. Trabalho com pequenas e grandes amostras textuais: levantamento de terminologias na área de pneumopatias ocupacionais. In: ISQUERDO, Aparecida Negri; DAL CORNO, Giselle Olívia Mantovanni (Ed.). As ciências do léxico: lexicologia, lexicografia, terminologia. Campo Grande: Editora da UFMS, 2018. p. 347-372.

FROMM, Guilherme. 2018. Vocabulário de linguística: treinamento em terminografia bilíngue, uso de corpora e ambiente de gestão terminológica. In: ISQUERDO, Aparecida Negri; DAL CORNO, Giselle Olívia Mantovanni (Ed.). As ciências do léxico: lexicologia, lexicografia, terminologia. Campo Grande: Editora da UFMS, 2018. p. 309-328. 
HALLIDAY, Michael A. K. Text as Semantic Choice in Social Context. In: VAN DIJK, Teun Adrianus; PETOFI, Janus S. (Ed.). Grammars and descriptions. Berlin: Walter de Gruyter, 1977. p. 176-225.

ISQUERDO, Aparecida Negri; FINATTO, Maria Jose B. As ciências do léxico: lexicologia, lexicografia, terminologia. Porto Alegre: Editora da UFRGS, 2010.

KELLY, Dorothy; MARTIN, Anne; NOBS, Marie-Louise; SÁNCHEZ, Dolores; WAY, Catherine. Reflexiones en torno a algunos conceptos básicos. In: KELLY, Dorothy; MARTIN, Anne; NOBS, Marie-Louise; SÁNCHEZ, Dolores; WAY, Catherine (Ed.). La direccionalidad en traducción e interpretación; perspectivas teóricas, profesionales y didácticas. Granada: Atrio, 2003. p. 33-41.

KELLOGG, Ronald T. Professional Writing Expertise. In: ERICSSON, K. Anders; CHARNESS, Neil; FELTOVITCH, Paul J.; HOFFMAN, Robert R. (Ed.). The Cambridge Handbook of Expertise and Expert Performance. Cambridge: CUP, 2006. p. 389-402.

https://doi.org/10.1017/CBO9780511816796.022.

KRIEGER, Maria da Graça. Do ensino da terminologia para tradutores: diretrizes básicas. Cadernos de Tradução, Florianópolis, v. 17, n. 1, p. 189-206, 2006.

NEWMARK, Peter. A Textbook of Translation. London: Prentice-Hall International, 1998.

PAGANO, Adriana Silvina; DA SILVA, Igor Antônio Lourenço. Domain knowledge in translation task execution: insights from academic researchers performing as translators. In: WORLD CONGRESS INTERNATIONAL FEDERATION OF TRANSLATORS, 18., 2008, Shanghai. Proceedings... Shanghai: Foreign Language Press, 2008. CD-ROM.

PAIVA, Paula Tavares Pinto; CAMARGO, Diva Cardoso de; XATARA, Cláudia Maria. Uma reflexão sobre a elaboração de um léxico bilíngue preliminar na subárea de cardiologia a partir do uso de termos encontrados em um corpus paralelo e em dois corpora comparáveis. D.E.L.T.A., São Paulo, v. 24, n. 1, p. 1-22, 2008. 
PAVLOVIĆ, Nataša. Directionality in Translation and Interpreting Practice: Report on a Questionnaire Survey in Croatia. Forum, Edinburgh, v. 5, n. 2, p. 79-99, 2007.

RIBEIRO, Rodrigo. The language barrier as an aid to Communication. Social Studies of Science, New York, v. 37, n. 4, p. 561-584, 2007. https://doi.org/10.1177/0306312706070738.

SCARDAMALIA. Marlene; BEREITER, Carl. Literate Expertise. In: ERICSSON, K. Anders; SMITH, John. Toward a general theory of expertise. Cambridge: CUP, 1991. p. 172-194.

DA SILVA, Igor Antônio Lourenço. On a more robust approach to triangulating retrospective protocols. In: FERREIRA, Aline; SCHWIETER, John W. (Org.). Psycholinguistic and Cognitive Inquiries into Translation and Interpreting. 1. ed. Amsterdam: John Benjamins Publishing Company, 2015, p. 175-201. https://doi.org/10.1075/btl.115.08sil.

DA SILVA, Igor Antônio Lourenço; SILVEIRA, Francine Assis. A expertise por interação como condicionante da competência do tradutor de textos técnicos e científicos. Domínios de Lingu@gem, v. 11, p. 1746-1763, 2017. http://orcid.org/0000-0003-0738-3262.

VASCONCELOS, Sonia M. R.; SORENSON, Martha M.; LETA, Jacqueline. Scientist-Friendly Policies for Non-Native English-Speaking Authors: Timely and Welcome. Brazilian Journal of Medical and Biological Research, Ribeirão Preto, v. 40, p. 743-747, 2007. https://doi.org/10.1590/S0100$\underline{\text { 879X2007000600001. }}$.

\begin{abstract}
This article discusses the role of interactional expertise in specialized translation. Interaction between translator and field specialist is proposed as fundamental to the production of specialized target texts that are adequate to the expectations of their target discourse communities. Two samples involving inverse translation from Portuguese into English are provided to show the impact of interactions with specialists on the translator's practice and reflection.
\end{abstract}

Keywords: Specialized translation; Interactional expertise; Longitudinal study. 


\section{Resumo}

Este artigo discute o papel da expertise por interação na tradução científica. Propõe-se que a interação entre o tradutor e o especialista da área seja fundamental para a produção de textos-alvo adequados às expectativas da comunidade discursiva para a qual se traduz. Fornecem-se dois exemplos envolvendo tradução inversa do português para o inglês a fim de mostrar o impacto que interações com especialistas podem ter na prática e na reflexão do tradutor.

Palavras-chave: Tradução especializada; Expertise por interação; Estudo longitudinal. 